\title{
ANALISIS FAKTOR-FAKTOR YANG MEMPENGARUHI KINERJA BANK UMUM YANG GO PUBLIC DI BURSA EFEK INDONESIA
}

\author{
Dian Heri Krisdianto ${ }^{1 *}$, Nurjanti Takarini ${ }^{2}$ \\ ${ }^{12}$ Manajemen, Fakultas Ekonomi dan Bisnis, UPN "Veteran" Jawa Timur \\ *Penulis Korespondensi; Email: Dianheri11@gmail.com ${ }^{1}$, yayannurjanti@yahoo.com²
}

\begin{abstract}
Basically, a company in carrying out operational activities of a bank has a mission to obtain maximum profit. Then banks are required to maintain financial ratios that are equivalent to Bank Indonesia policies and pay attention to their capabilities so that they are always trusted by customers and investors. Judging from the performance of banks shows that the profit generated there is a downward trend, then indirectly the performance of the banking sector also declined. From the problems above, the purpose of this study was to determine the effect of CAR, BOPO, NPL, NIM, and LDR on the performance of public banks that were listed on the IDX in the 2014-2018 timeframe. The population in this study consisted of 37 banking companies listed on the IDX. And the sample selection technique used in this study using purposive sampling, which was based on several criteria, from these criteria, which can be used as a sample there were 27 commercial banks. While the data analysis technique used in this study was multiple linear regression analysis. Based on the results of the meal study, it can be concluded that Operational Expenses and Operating Income (BOPO), Net Interest Margin (NIM), and Loan to Deposit Ratio (LDR) affect the performance of public cattle which was proxied by Return on Assets (ROA), and for Capital Adequecy Ratio (CAR) and Non Performing Loan (NPL) did not affect the performance of commercial banks which was proxied by Return on Assets (ROA).
\end{abstract}

Keywords: Capital adequecy ratio, non performing loan, return on assets, operational expenses and operating income, net interest margin.

\section{Pendahuluan}

Perbankan saat ini memiliki peranan yang sangat penting dalam sistem keuangan, sehingga perlu adanya pemahaman dan pengelolaan Bank yang baik dan efisien, maka dapat mendorong sistem keuangan yang baik dan optimal. Pemahaman dapat diketahui apabila ada penjelasan tentang bagaimana cara mengelola rasio keuangan, penilaian kinerja dan tingkat kesehatan yang baik dan optimal. Dari dasar di atas maka materi tentang anlisis rasio keuangan perbankan dirasakan masih sangat dibutuhkan demi kepentingan semua pihak. Dalam upaya meningkatkan pertumbuhan ekonomi dan kesejahteraan masyarakat, pihak pemerintah menyadari bahwa peranan bank sangat penting. Fungsi bank adalah suatu lembaga keungan yang aktivitasnya menghimpun dana berupa giro, deposito tabungan dan simpanan yang lain dari pihak yang kelebihan dana (surplus spending unit), kemudian menyalurkan kembali kepada masyarakat yang membutuhkan dana (deficit spending unit) melalui penjualan jasa keuangan yang bertujuan untuk meningkatkan kesejahteraan rakyat banyak.

Lembaga perbankan yang memiliki sifat "khusus" hal ini bisa di lihat dalam perspektif mikro dan makro. Pada perspektif mikro, bank dapat mendorong perkembangan ekonomi negara dengan cara memberikan penyaluan jasa kredit. Dilihat dari perspektif makro, kebijakan moneter yang ditetapkan lembaga perbankan menjaga stabilisasi ekonomi yang dapat diukur dengan kesempatan kerja, kestabilan harga serta neraca pembayaran internasional yang seimbang. Oleh sebab itu, dalam menjaga keseimbangan ekonomi negara diperlukan pengaturan dan kontrol yang eksklusif bagi perbankanyaitu Bnak Indonesia.

Bank Indonesa selaku bank sentral berperan sangat penting dalam mengelola kesehatan perbankan di Indonesia. Oleh karena itu, Bank Indonesia mengeluarkan mengenai kesehatan bank. Dalam pengukuran kesehatan bank yang dijalankan Bank Indonesia mengacu pada analisis CAMEL, yang menerangkan dari aspek capital, asset, management, earning, dan liquidity. 
Selama ini untuk mengetahui tingkat kesehatan bank digunakan analisis CAMEL, sedangkan dalam penelitian ini berbeda dengan kriteria yang ditetapkan Bank Indonesia untuk menentukan kesehatan bank dalam penelitian ini menggunakan kinerja perbankan yang diukur dengan ROA yang dipakai sebagai variabel dependen karena memiliki alasan bahwa dalam menilai efektifitas perusahaan guna memanfaaatkan aset yang dimiliki dan dalam menghasilkan keuntungan yaitu menggunakan Return On Asset (ROA).

Return On Asset (ROA) adalah kemampuan perusahaan dalam memperoleh laba dengan menggunakan seluruh asset yang dikelolanya, sehingga Return On Asset (ROA) dijadikan alat ukur kinerja perbankan. Selain itu Return On Asset (ROA) juga mencerminkan kemampuan manajemen bank dalam mengelola assetnya secara efektif (Siswanto, 2004). Dengan demikian rasio Return On Asset (ROA) yang dihasilkan tinggi maka semakin baik atau sehat kinerja bank tersebut, karena dengan meningkatnya Return On Assets (ROA), maka kemampuan perbankan memperoleh laba sesudah pajak dapat menggunakan asset. Adapun Return On Assets (ROA) pada bank umum yang go public di BEI periode 2014-2018 ada kecenderungan trend menurun, perkembangan ROA dapat dilihat pada Tabel 1.

Tabel 1

Perkembangan ROA Bank Umum Go Public di BEI Periode 2014-2018

\begin{tabular}{lccccc}
\hline \multicolumn{1}{c}{ Tahun } & 2014 & 2015 & 2016 & 2017 & 2018 \\
\hline Rata-rata Return On Assets (ROA) & 1,40 & 1,80 & 0,61 & 0,93 & 0,96 \\
Pertumbuhan rata-rata ROA & $-0,20$ & $-0,23$ & $-0,44$ & 0,52 & 0,03 \\
\hline
\end{tabular}

Sumber: www.idx.co.id (data diolah)

Pada data pada Tabel 1 dapat diamati rata-rata ROA untuk 27 perusahaan perbankan dari rentan waktu 2014 sampai 2018 menyatakan hasil kenaikan pada tiga tahun terakhir. Akan tetapi, jika dilihat pertumbuhan rata-rata Return On Assets perusahaan perbankan pada 2014-2018 nampak adanya fluktuasi. Pada 2014 ROA perusahaan perbankan sebesar $-0,20 \%$, saat 2015 turun diangka $-0,23 \%$, saat 2016 turun di angka $-0,44 \%$, saat 2017 naik diangka 0,52\%, dan pada 2018 menurun di angka $0,03 \%$. Naik turunnya rata-rata Return On Assets (ROA) yang tidak pasti tersebut menyatakan adanya masalah pada kinerja perbankan.

Kinerja perbankan secara keseluruhan merupakan prestasi yang dicapai perbankan dalam kegiatan opersaionalnya, baik dari aspek keuangan, pemasaran, penyimpanan dan penyaluran dana ke masyarakat. Kinerja keuangan perbankan memberikan gambaran kondisi keuangan perbankan dalam menyimpan dan menyalurkan. Adapun aspek yang mempengaruhi pada kinerja bank, yaitu: Capital Adequacy Ratio (CAR), Beban Operasional dan Pendapatan Operasional (BOPO), Non Performing Loan (NPL), Net Interest Margin (NIM), dan Loan to Deposit Ratio (LDR) (Purnomo, Sriwidodo, \& Wibowo, 2018).

Menurut Purnomo dkk. (2018) CAR merupakan indikator kemampuan bank untuk menutup penurunan aktivanya akibat kerugian-kerugian yang dialami. Jika modal suatu bank yang dimiliki dapat menyerap kerugian-kerugian, maka bank dapat mengelola seluruh kegiatan secara efisien, sehingga diharapkan laba bank juga akan meningkat demikian juga sebaliknya, maka CAR berpengaruh terhadap profitabilitas.

Beban Operasional dan Pendapatan Operasional (BOPO) (Purnomo dkk., 2018) rasio ini dipakai guna menilai kualitas efisiensi dan kebisaan bank untuk menjalankan aktivitas kinerjanya. Makin rendah rasio ini berarti makin efisien biaya operasional yang dikelola bank, maka memungkinkan bank berada dalam masalah makin kecil maka laba yang diharapkan akan meningkat.

Non Performing Loan (NPL) yakni rasio yang digunakan guna menilai kapabilitas bank mengambilalih risiko pengembalian kredit pada debitur. Jika makin besar NPL maka akan makin tinggi kemacetan bunga kredit, sehingga berakibat berkurangnya penghasilan bunga dan berkurangnya keuntungan (Purnomo dkk., 2018).

Net Interest Margin (NIM) digunakan untuk mengukur kemampuan manajemen bank dalam mengelola aktiva produktifnya untuk menghasilkan pendapatan bunga bersih, berarti jika rasio NIM meningkat maka perbankan akan menghasilkan laba yang lebih baik atau meningkat. 
Loan to Deposit Ratio merupakan rasio yang menjelaskan kualitas likuiditas sebuah bank, serta kapabilitas untuk melakukan manfaat intermediasinya guna memberikan dana pihak ketiga ke kredit (Purnomo dkk., 2018).

\section{Kajian Teoritis dan Hipotesis}

Menurut Pinasti dan Mustikawati (2018) menyatakan bahwa CAR dan LDR berpengaruh negatif dan tidak siginifikan terhadap profitabilitas, BOPO berpengaruh negatif dan siginifikan terhadap profitabilitas, NPL berpengaruh positif dan tidak siginifikan terhadap profitabilitas, dan NIM berpengaruh positif dan siginifikan terhadap profitabilitas. Adapun menurut Dewi (2017) yang menyatakan bahwa CAR, dan NIM tidak signifikan mempengaruhi ROA, sedangkan BOPO, NPL, dan LDR secara signifikan mempengaruhi ROA.

Nugroho, Mangantar, dan Tulung (2019) menyatakan bahwa secara parsial CAR dan NIM berpengaruh signifikan positif terhadap ROA, sedangkan BOPO dan NPL tidak berpengaruh signifikan negatif terhadap ROA dan untuk uji simultan menunjukkan bahwa CAR, BOPO, NIM, NPL secara bersama-sama berpengaruh signifikan terhadap ROA. Menurut Korri dan Baskara (2019) menunjukkan bahwa CAR berpengaruh positif tidak signifikan terhadap profitabilitas. LDR berpengaruh positif dan signifikan terhadap profitabilitas. NPL dan BOPO berpengaruh negatif signifikan terhadap profitabilitas.

\section{Return On Assets (ROA)}

Return on Assets (ROA) dipakai sebagai menilai kapabilitas bank dalam mendapatkan laba serta mengolah seluruh kualitas efisien suatu bank. Bank Indonesia menerangkan, ROA ialah perpaduan dari laba sebelum pajak oleh rata-rata keseluruhan aset pada satu rentang waktu. Jika ROA semakin besar berarti manajemen perusahaan makin bagus, karena nilai pengembalian makin besar. Maka pada observasi ini digunakan ROA untuk indikator penilaian kemampuan manajemen bank.

Return on Assets diambil untuk parameter penilaian kinerja manajemem bank sebab ROA dapat dipakai guna menilai keefektif an perusahaan untuk memperoleh laba untuk menggunakan aktiva yang dipunya. Profitabilitas ialah parameter yang tepat guna mengukur kinerja manajemen bank (Dewi, 2017).

\section{Capital Adequecy Ratio (CAR)}

CAR yakni rasio yang bersangkutan pada aspek modal bank guna menilai keukupan modal yang dipunya bank guna mendukung aktiva yang terdapat risiko (Purnomo dkk., 2018). Rasio CAR dipakai guna menilai kapabilitas modal yang ada sebagai mengatasi kerugian didalam aktivitas perkreditan serta perdagangan surat-surat berharga. Semakin besar rasio ini maka makin bagus keadaan modal. Bank diharuskan dapat menjalankan tanggung jawab keharusan modal minimum. Sejalan pada standar yang ditetapkan Surat Edaran BI nomor 15/12/PBI/2013, yakni: semua bank yang terdapat di Indonesia diharuskan dalam mencadangkan modal minimum $8 \%$ pada ATMR.

\section{Beban Operasional pada Pendapatan Operasional (BOPO)}

Rasio BOPO juga bisa disebut rasio efisiensi yang dipakai guna menilai kapabilitas perbankan guna menjaga kestabilan anggaran operasional pada pendapatan operasional. Jika BOPO makin turun jadi makin efektif pengeluaran anggaran operasional bank, atau pada maksud berbeda jika makin tinggi BOPO, sehingga memungkinkan masalah bank makin besar (Purnomo dkk., 2018).

Rasio BOPO digunakan untuk menilai pendapatan operasional untuk menutup anggaran operasional. BI memberikan nilai terbaik pada BOPO yakni lebih rendah dari $90 \%$, sebab apabila BOPO lebih dari $90 \%$ sampai menyentuh nilai $100 \%$ jadi bank bisa dikatakan kurang baik untuk menjalankan kegiatan operasional.

\section{Non Performing Loan (NPL)}

Menurut Korri dan Baskara (2019) NPL yakni perbandingan dari jumlah masalah kredit pada jumlah kredit yang disalurkan pada debitur. Risiko kredit ialah risiko yang didapat bank diakibatkan 
penyaluran dananya pada stuktur pinjaman pada masyarakat. Akibat beberapa sebab, debitur kemungkinan belom bisa membayar keharusan bank yakni membayar pokok pinjaman, pembiayaan bunga serta lainnya.

NPL menjelaskan kapabilitas manajemen bank untuk mengolah permasalahan kredit pada bank. Bank saat menyalurkan kredit harus memperhatikan penilaian kepada kapabilitas debitur saat keharusan memenuhi tanggung jawabnya. Sesudah kredit disalurkan, bank diharuskan memantau pada pemanfaatan kredit dan kapabilitas debitur saat membayar kembali kreditnya. Bank perlu untuk menilai, meninjau, dan pengikatan pada agunan guna meminialisir risiko kredit.

\section{Net interest Margin (NIM)}

Net Interest Margin berguna dalam menilai kapabilitas bank untuk mengatasi risiko pada suku bunga. Berubahnya suku bunga, juga akan mengubahn penerimaan bunga dan anggaran bunga. Makin tinggi NIM dapat meningkatkan penghasilan bunga pada aktiva produktif yang dioperasikan bank maka memungkinkan bank memiliki masalah makin kecil (Purnomo dkk., 2018).

NIM menjelaskan kapabilitas manajemen bank untuk menjalankan aktiva produktifnya dalam memperoleh penghasilan bunga bersih. Perolehan bunga bersih didapat dari penghasilan bunga dikurang dengan biaya bunga.

\section{Loan to Deposit Ratio (LDR)}

Loan to Deposit Ratio dipakai guna memperkirakan likuiditas bank dengan cara membagi keseluruhan kredit yang disalurkan bank pada dana pihak ketiga (Purnomo dkk., 2018). LDR dipakai untuk memperhitungkan likuiditas bank dengan membagi keseluruhan kredit dengan keseluruhan dana.

Ketetapan LDR berdasarkan Surat Edaran BI Nomor 15/7/PBI/2013 bahwa standar LDR di angka $78 \%$ sampai $92 \%$. Apabila LDR berada di angka kurang dari 78\%, berarti bank tersebut tidak bisa memeberikan kembali secara efisien semua dana yang telah didapat. Akan tetapi, apabila nilainya melebihi angka 92\%, maka jumlah kredit yang diberikan bank melampaui dana yang diperoleh (Korri \& Baskara, 2019).

\section{Pengaruh Capital Adequecy Ratio (CAR) pada ROA \\ Pengembangan Hipotesis}

CAR ialah perbandingan dari modal pada aktiva tertimbang menurut risiko dan memenuhi peraturan pemerintah (Kasmir, 2014). CAR kurang dari 8\% tidak memiliki kemungkinan untuk menyalurkan kredit atau bisa dikatakan di bawah ketentuan standar kecukupan modal. Menurut Nugroho dkk. (2019) menjelaskan jika CAR memiliki pengaruh signifikan positif terhadap ROA. Jadi permodalan perbankan mempengaruhi profitabilitas. Apabila CAR telah sesuai ketetapan, maka bank bisa menjalankan kinerjanya dengan baik, dan pada akhirnya memperoleh keuntungan. Seperti halnya, jika suatu bank makin besar nilai CAR, maka makin bagus pula kinerja bank tersebut. Pemberian kredit secara efisien, dengan dugaan tidak kejadian macet akan meninggkatkan laba perusahaan yang kemudian akan menaikkan ROA. Jika bank memiliki modal yang besar, akan berdampak terhadap tingkat kepercayaan masyarakat pada kinerja bank. Berdasarkan pendapat tersebut di atas, maka dapat dihipotesiskan seperti berikut:

Hipotesis 1: CAR memiliki pengaruh positif pada kinerja bank.

\section{Pengaruh Beban Operasional dan Pendapatan Operasional (BOPO) pada ROA}

Rasio BOPO ialah rasio pembanding pada anggaran opersional oleh pendapatan operasional. Jika makin tinggi BOPO, maka juga makin kecil atau memburuk kinerja perbankan atau sebaliknya, jika suatu bank nilai BOPO yang dimiliki meningkat kemudian akan semakin membaik kinerja perbankan. Hal tersebut didukung dengan penelitian Purnomo dkk. (2018) menyatakan Beban Operasional Dan Pendapatan Operasional (BOPO) memiliki pengaruh signifikan negatif pada ROA. Menurut Pinasti dan Mustikawati (2018) menjelaskan jika BOPO berdampak dengan arah negatif dan signifikan pada ROA, artinya apabila BOPO mengalami kenaikan yang dimaksudkan tingkat efisien turun, maka ROA juga turun. Jika makin efisien bank, maka kinerjanya makin menigkat. Jika kinerja 
suatu bank naik, maka dapat meningkatkan keyakinan masyarakat pada bank. Berdasarkan pendapat tersebut, maka dapat dihipotesiskan seperti berikut:

Hipotesis 2: BOPO memiliki pengaruh negatif pada kinerja bank

\section{Pengaruh Non Performing Loan (NPL) pada ROA}

Menurut Korri dan Baskara (2019) NPL ialah suatu rasio keuangan yang menecerminkan risiko kredit. Bank bisa melaksanakan kegiatan operasi secara lancar jika memiliki NPL kurang dari 5\%. Jika makin besar nilai NPL hingga makin turun tingkat kredit yang mengakibatkan keseluruhan masalah kredit makin naik hingga menyebabkan bank memiliki masalah. Dengan demikian kenaikan NPL mengakibatkan laba menurun, dengan penjelasan lain kinerja bank turun. Dewi (2017) menyatakan bahwa NPL berpengaruh signifikan negatif pada ROA. Karena disebabkan oleh kebijakan BI mengenai NPL jika peningkatan outstanding pinjaman yang diberikan, maka wajib dijamin dengan cadangan penghapusan aktiva produktif dengan aturan mendebit rekening anggaran cadangan penghapusan aktiva produktif dan yang akan berdampak pada Return On Assets (ROA). Berdasarkan pendapat tersebut, maka dapat dihipotesiskan seperti berikut:

Hipotesis 3: NPL memiliki pengaruh negatif pada kinerja bank.

\section{Pengaruh Net Interest Margin (NIM) pada ROA}

NIM berdampak dari transisi suku bunga dan kapabilitas aktiva produktif. Dalam menyalurkan kreditnya bank perlu berjaga-jaga supaya kapasitas aktiva produktifnya selalu normal. Dengan kapasitas produktif suatu bank yang baik bisa menaikkan perolehan bunga bersih dan akan menaikkan laba sebelum pajak, maka ROA juga mengalami kenaikan. Hal ini didukung pada hasil penelitian Purnomo dkk. (2018) yang membuktikan jika NIM memiliki pengaruh signifikan positif pada ROA. Dari tiap kenaikan NIM, maka dapat meningkatkan ROA. Ini terjadi disebabkan pada tiap kenaikan perolehan bunga bersih, yakni pautan dari penjumlahan anggaran bunga dengan penjumlahan penerimaan bunga menyebabkan naiknya pendapatan sebelum pajak, sehingga kemudian ROA juga meningkat. Pinasti dan Mustikawati (2018) juga menyatakan bahwa makin tinggi NIM, maka makin besar profitabilitas. Berdasarkan pendapat tersebut, maka dapat dihipotesiskan seperti berikut:

Hipotesis 4: NIM memiliki pengaruh positif pada kinerja bank.

\section{Pengaruh Loan to Deposit Ratio (LDR) pada ROA}

Kenaikan LDR diartikan pemberian dana ke peminjam semakin tinggi, sehingga keuntungan juga meningkat. Naiknya keuntungan yang terjadi menimbulkan kinerja bank yang dinilai oleh ROA yang makin naik. Ide ilmu ini didukung pada hasil penelitian Dewi (2017) yang menjelaskan bahwa LDR memiliki pengaruh signifikan positif pada ROA. Semakin naik nilai LDR hingga keterbatasannya, maka makin tinggi dana yang diberikan pada jenis kredit, sehingga menaikkan perolehan bunga. Tambahan bunga ini bisa menaikkan keuntungan yang didapat, yang bisa diproksikan dengan ROA. Menurut Korri dan Baskara (2019) menjelaskan LDR meningkat, maka profitabilitas yang diperoleh bank juga akan meningkat. Hal ini menunjukkan kinerja bank ketika memberikan kredit kepada pihak ketiga cukup baik. Berdasarkan pendapat tersebut, maka dapat dihipotesiskan seperti berikut:

Hipotesis 5: LDR memiliki pengaruh positif pada kinerja bank.

Variabel yang dipakai dalam observasi ini :

\section{Metode Penelitian}

\section{Return On Assets ( $Y)$}

Return On Assets dalam penilaian sederhana dihitung dari laba dibagi aktiva. ROA dipakai untuk proksi dalam menilai profitabilitas bank. Rasio ini bermanfaat bagi analis kinerja perusahaan. ROA yang dipakai dalam penelitian ini dari Surat Edaran BI Nomor 13/24/DPNP tanggal 25 Oktober 2011 yang dirumuskan, seperti berikut: 
$R O A=\frac{\text { Laba Sebelum Pajak }}{\text { TotalAssets }} \times 100 \%$

\section{Capital Adequecy Ratio $\left(X_{I}\right)$}

Dalam riset ini indikator dari aktivitas yang dipakai adalah rasio Capital Adequecy Ratio yaitu untuk menilai ketersediaan modal bank guna menjaga aktiva bank yang mengandung risiko (Aktiva Tertimbang Menurut Risiko/ATMR). Rasio ini dapat diterangkan dalam Surat Edaran Bank Indonesia No. 6/23/DPNP Tahun 2004, yaitu:

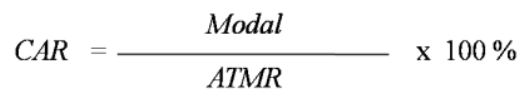

3. Beban Operasional dan Pendapatan Operasional $\left(X_{2}\right)$

Dalam riset ini indikator dari aktivitas yang dipakai adalah rasio BOPO yakni perbandingan penjumlahan biaya pendapatan oleh jumlah penghasilan operasional. Pendapatan operasional ialah total dari jumlah penghasilan bunga dan jumlah penghasilan operasional yang lain. Hal ini dijelaskan seperti dalam Surat Edaran Bank Indonesia No. 6/23/DPNP Tahun 2004, yaitu:

$$
\text { BOPO }=\frac{\text { Biaya Operasional }}{\text { Pendapatan Operasional }} \quad \times 100 \%
$$

\section{Non Performing Loan $\left(X_{3}\right)$}

Penilaian kredit didapat pada NPL. Menurut Dewi (2017) menyatakan bahwa NPL yakni rasio dari permasalahan kredit pada kredit yang disalurkan. NPL dijelaskan dalam Peraturan Bank Indonesia No. 13/1/PBI/2011 tentang rasio Non Performing Loan bisa dinilai pada rumus, yakni:

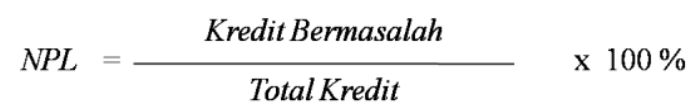

\section{Net Interest Margin $\left(X_{4}\right)$}

Net Interest Margin dipakai guna menilai rasio pasar. NIM ialah kesetaraan dari penghasilan bunga bersih dengan rata-rata aktiva produktifnya. NPL dijelaskan seperti pada Surat Edaran Bank Indonesia No. 6/23/DPNP Tahun 2004, yaitu:

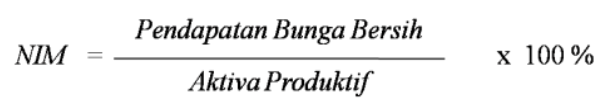

\section{Loan to Deposit Ratio $\left(X_{5}\right)$}

Observasi pada indikator dari aktivitas yang dipakai adalah rasio LDR, dalam hal ini guna menilai kapabilitas bank untuk mencukupi pembiayaan lagi deposito yang sudah waktunya pada deposannya dan untuk mencukupi perizinan kredit diberkan tanpa terjadi permasalahan. LDR dijelaskan seperti pada Surat Edaran Bank Indonesia No. 6/23/DPNP Tahun 2004, yaitu:

$$
L D R=\frac{\text { Kredityang diberikan }}{\text { Total Dana Pihak Ketiga }} \quad \times 100 \%
$$

\section{Populasi dan Sampel Penelitian}

Populasi pada riset ini yaitu perusahaan perbankan yang terdaftar di BEI tahun 2014-2018. Jumlah populasi dari perusahaan tersebut adalah 41 perusahaan. Teknik pemilihan sampel yang dipakai yaitu purposive sampling. Dari 41 perusahaan hanya diambil 27 perusahaan bank yang terdaftar di BEI periode 2014-2018 berlandaskan kriteria yang sudah ditetapkan.

Berdasarkan tolok ukur pada Tabel 2, sampel yang bisa dipakai untuk bahan riset yaitu 27 Perusahaan perbankan. Kemudian dikalikan dengan 5 tahun periode riset yaitu mulai 2014-2018. Jadi, 
total terdapat 135 unit data observasi ( 27 x 5) dalam riset ini. Teknik analisis data telah dipakai untuk riset ini yaitu dengan analisis regresi linier berganda pada metode kuantitatif dan memakai software SPSS 24 for Windows.

Tabel 2

Hasil Pemilihan Sampel

\begin{tabular}{lc}
\hline \multicolumn{1}{c}{ Keterangan } & Jumlah Perusahaan \\
\hline Perusahaan perbankan yang terdaftar di BEI periode 2014-2018 & 41 \\
Perusahaan perbankan yang belum listing di BEI periode 2014-2018 & $(4)$ \\
Perusahaan perbankan yang delisting di BEI periode 2014-2018 & $(4)$ \\
Perusahaan perbankan yang memiliki nilai Return On Assets (ROA) negatif periode 2014-2018 & $(6)$ \\
Jumlah sampel penelitian & 27 \\
\hline
\end{tabular}

\section{Analisis Data dan Pembahasan Uji Outlier}

Outlier ialah data yang mempunyai keunikan khas dan kelihatan berbeda sekali dari data observasi yang lainnya (nilai ekstrim). Ditemukan outlier jika mahal. Distance maximum $>$ Probability dan Jumlah variabel $[=\operatorname{CHIINV}(0,001 ; 6)$ : dicari melalui Excel $]=22,458$.

Penilaian analisis deteksi adanya outlier data ini pada analisis pertama terdapat nilai mahal. Distance maximum yang lebih besar dari 22,458 (46,762 > 22,458). Berarti terdapat outlier pada data ini. Data tersebut mempunyai kualitas yang tidak baik karena ditemukan outlier pada data ini. Terdapat case yang harus dikeluarkan yaitu empat case. Selanjutnya data diuji kualitas lagi.

Hasil analisis deteksi adanya outlier data ini pada analisis tidak terdapat nilai mahal. Distance maximum yang lebih kecil dari 22,458. Berarti tidak terdapat outlier pada data tersebut, yaitu 20,847 < 22,458, maka data ini memiliki bobot yang baik, sehingga data bisa diolah kelanjutannya.

\section{Uji Normalitas}

\section{Uji Asumsi Klasik}

Uji normalitas dalam penelitan ini mengunakan metode uji Kolmogorov Smirnov. Uji Kolmogorov Smirnov digunakan unurk mengetahui distribusi data, apakah mengetahui distribusi normal, paisom, uniform, atau exponential. Dalam hal ini untuk mengetahui apakah distribusi residual terdistribusi normal atau tidak. Residual berdistribusi normal jika nilai signifikan 0,05. Hasilnya dapat dilihat pada Tabel 3.

\section{Tabel 3}

Hasil Uji Normalitas (One-Sample Kolmogorov-Smirnov Test)

\begin{tabular}{llrrrrr}
\hline & & $X_{1}=\mathrm{CAR}$ & $X_{2}=\mathrm{BOPO}$ & $X_{3}=\mathrm{NPL}$ & $X_{4}=\mathrm{NIM}$ & $X_{5}=\mathrm{LDR}$ \\
\hline$N$ & & 131 & 131 & 131 & 131 & 131 \\
Normal Parameters & Mean & 20.4782 & 83.6734 & 2.4510 & 5.3902 & 84.9662 \\
& Std. Deviation & 4.85524 & 10.2108 & 1.3719 & 1.93147 & 12.70599 \\
Most Extreme & Absolute & .090 & .092 & .102 & .152 & .097 \\
Differences & Positive & .090 & .061 & .102 & .152 & .051 \\
& Negative & -.041 & -.092 & -.040 & -.110 & -.097 \\
Test Statistic & & .090 & .092 & .102 & .152 & .097 \\
Asymp. Sig. (2-tailed) & & $.011^{\mathrm{c}}$ & $.008^{\mathrm{c}}$ & $.002^{\mathrm{c}}$ & $.000^{\mathrm{c}}$ & $.004^{\mathrm{c}}$ \\
\hline
\end{tabular}

a. Test distribution is normal.

b. Calculated from data.

a. Lilliefors significance correction.

Diperoleh hasil analisis bahwa variable CAR $\left(X_{1}\right)=0,011$, BOPO $\left(X_{2}\right)=0,008$, NPL $\left(X_{3}\right)=$ 0,002 , NIM $\left(X_{4}\right)=0,000$, dan LDR $\left(X_{5}\right)=0,004$, dari semua di atas residual tidak berdistribusi normal karena signifikannya $<0,05$. Walaupun semua tidak berdistribusi normal, akan tetapi dari hasil uji kualitas data menunjukkan bahwa tidak ada outlier di data ini, maka data ini memiliki kapasitas baik dan bisa dilanjutkan pengolahan lebih lanjut. 
Berdasarkan "central limit of theorem" jumlah data yang diolah termasuk data besar, yaitu lebih dari 30. Dengan demikian dapat diasumsikan bahwa data dianggap berdistribusi normal (Sekaran, 2006)

\section{Uji Multikolinieritas}

Uji multikolonieritas bertujuan untuk menguji apakah dalam model regresi ditemukan adanya korelasi antar variabel bebas (independen). Hasilnya dapat dilihat pada Tabel 4.

Tabel 4

Hasil Uji Multikolinieritas

\begin{tabular}{|c|c|c|c|c|c|c|c|}
\hline \multirow[b]{2}{*}{ Model } & \multicolumn{2}{|c|}{$\begin{array}{c}\text { Unstandardized } \\
\text { Coefficients }\end{array}$} & \multirow{2}{*}{$\begin{array}{c}\begin{array}{c}\text { Standardized } \\
\text { Coefficients }\end{array} \\
\text { Beta }\end{array}$} & \multirow[b]{2}{*}{$T$} & \multirow[b]{2}{*}{ Sig. } & \multicolumn{2}{|c|}{ Collinearity Statistics } \\
\hline & $B$ & $\begin{array}{c}\text { Std. } \\
\text { Error }\end{array}$ & & & & Tolerance & $V I F$ \\
\hline (Constant) & 8.790 & .410 & & 21.459 & .000 & & \\
\hline$X_{l}=\mathrm{CAR}$ & -.009 & .006 & -.040 & -1.491 & .138 & .842 & 1.188 \\
\hline$X_{2}=\mathrm{BOPO}$ & -.087 & .003 & -.829 & -28.401 & .000 & .702 & 1.424 \\
\hline$X_{3}=$ NPL & -.017 & .021 & -.022 & -.824 & .411 & .822 & 1.216 \\
\hline$X_{4}=\mathrm{NIM}$ & .149 & .016 & .268 & 9.488 & .000 & .747 & 1.339 \\
\hline$X_{5}=\mathrm{LDR}$ & -.004 & .002 & -.047 & -1.745 & .083 & .820 & 1.220 \\
\hline
\end{tabular}

a. Dependent Variable: $Y=\mathrm{ROA}$

Multikolinieritas ialah pengujian yang berfungsi untuk mendeteksi terjadi korelasi variabel independen pada regresi berganda. Pengujian asumsi klasik multikolineritas di analisis regresi linier berganda ini menerangkan jika untuk variabel CAR $\left(X_{1}\right)=1,188$, BOPO $\left(X_{2}\right)=1,424$, NPL $\left(X_{3}\right)=$ 1,216, NIM $\left(X_{4}\right)=1,339$, dan LDR $\left(X_{5}\right)=1,220$, tidak menjelaskan terdapat gejala multikolinieritas sebagaimana perolehan VIF di variabel kurang dari 10, VIF (Variance Inflation Factor) $>10$ (Cryer \& Miller, 1994).

\section{Uji Heterokedastisitas}

Heteroskedastisitas adalah uji yang dipakai untuk melihat versi pada residual oleh satu observasi ke observasi lainnya yang berbeda versi. Hasil analisis uji heterokedastisitas yang menggunakan uji Rank Spearman's menjelaskan bahwa variabel CAR $\left(X_{I}\right)=0,610$, BOPO $\left(X_{2}\right)=0,350$, NPL $\left(X_{3}\right)=0,917$, NIM $\left(X_{4}\right)=0,526$, dan $\operatorname{LDR}\left(X_{5}\right)=0,754$, tidak mempunyai korelasi yang signifikan antara residual dengan variabel bebasnya, dimana nilai signifikansi masing-masing variabel $>0,05$.

Oleh karena itu, bisa ditetapkan bahwa tidak timbul heteroskedastisitas dan bisa dikatakan bahwa semua variabel observasi memenuhi asumsi heteroskedastisitas. Hasilnya dapat dilihat pada Tabel 5 .

\section{Uji Autokerelasi}

Uji autokorelasi bertujuan menguji apakah dalam model regresi linier ada korelasi antara kesalahan pengganggu pada periode $t$ dengan kesalahan pengganggu pada periode $t$-1 (sebelumnya). Jika terjadi korelasi, maka dinamakan ada problem autokorelasi.

Autokorelasi muncul karena observasi yang berurutan sepanjang waktu berkaitan satu sama lainnya. Ini menunjukkan hasil bahwa nilai Durbin Watson sebesar 1,665 angka berada di daerah antara. Di antara -2 sampai +2 tidak ada autokorelasi. Jadi hal ini menunjukkan tidak ada gejala autokorelasi. Dapat dilihat pada Tabel 6. 


\section{Tabel 5}

\begin{tabular}{|c|c|c|c|}
\hline & & & $\begin{array}{c}\text { Unstandardized } \\
\text { Residual }\end{array}$ \\
\hline & \multirow{3}{*}{ Unstandardized Residual } & Correlation Coefficient & 1.000 \\
\hline & & Sig. (2-tailed) & \\
\hline & & $N$ & 131 \\
\hline & \multirow[t]{3}{*}{$X_{I}=\mathrm{CAR}$} & Correlation Coefficient & .045 \\
\hline & & Sig. (2-tailed $)$ & .610 \\
\hline & & $N$ & 131 \\
\hline & \multirow[t]{2}{*}{$X_{2}=\mathrm{BOPO}$} & Correlation Coefficient & -.082 \\
\hline & & Sig. (2-tailed) & .350 \\
\hline \multirow{10}{*}{$\begin{array}{l}\text { Spearman's } \\
\text { rho }\end{array}$} & \multirow{4}{*}{$X_{3}=\mathrm{NPL}$} & $N$ & 131 \\
\hline & & Correlation Coefficient & .009 \\
\hline & & Sig. (2-tailed) & .917 \\
\hline & & $N$ & 131 \\
\hline & \multirow[t]{3}{*}{$X_{4}=\mathrm{NIM}$} & Correlation Coefficient & -.056 \\
\hline & & Sig. (2-tailed) & .526 \\
\hline & & $\mathrm{N}$ & 131 \\
\hline & \multirow[t]{3}{*}{$X_{5}=\mathrm{LDR}$} & Correlation Coefficient & .028 \\
\hline & & Sig. (2-tailed) & .754 \\
\hline & & $\mathrm{N}$ & 131 \\
\hline
\end{tabular}

* Correlation is significant at the 0.05 level (2-tailed).

** Correlation is significant at the 0.01 level (2-tailed).

Tabel 6

Hasil Uji Autokorelasi

\begin{tabular}{|c|c|c|c|c|c|c|c|}
\hline \multirow{2}{*}{ Model } & \multirow{2}{*}{$R$} & \multirow{2}{*}{$R$ Square } & \multirow{2}{*}{$\begin{array}{l}\text { Adjusted } \\
R \text { Square }\end{array}$} & \multirow{2}{*}{$\begin{array}{l}\text { Std. Error of } \\
\text { the Estimate }\end{array}$} & \multicolumn{2}{|c|}{ Change Statistics } & \multirow{2}{*}{$\begin{array}{l}\text { Durbin- } \\
\text { Watson }\end{array}$} \\
\hline & & & & & $R$ Square Change & Sig. F Change & \\
\hline 1 & $.962^{\mathrm{a}}$ & .925 & .922 & .29816 & .925 & .000 & 1.665 \\
\hline
\end{tabular}

a. Predictors: $($ Constant $), X_{5}=\mathrm{LDR}, X_{3}=\mathrm{NPL}, X_{1}=\mathrm{CAR}, X_{4}=\mathrm{NIM}, X_{2}=\mathrm{BOPO}$

b. Dependent Variable: $Y=\mathrm{ROA}$

Jadi bisa ditarik kesimpulan model regresi linier berganda yang didapatkan dalam riset mencukupi asumsi klasik.

\section{Hasil Regresi Berganda}

Analisis regresi linier berganda yang dipakai guna riset ini guna melihat kekuatan variabel bebas saat menerangkan variabel terikat dianalisis dari koefisien determinasi $\left(R^{2}\right)$. Dengan demikian dijelaskan hasil analisis regresi seperti pada Tabel 7.

\section{Tabel 7}

Hasil Regresi Linier Berganda

\begin{tabular}{|c|c|c|c|c|c|c|c|c|}
\hline & \multirow{2}{*}{ Model } & \multicolumn{2}{|c|}{$\begin{array}{l}\text { Unstandardized } \\
\text { Coefficients }\end{array}$} & \multirow{2}{*}{$\begin{array}{c}\text { Standardizd } \\
\text { Coefficients } \\
\text { Beta }\end{array}$} & \multirow{2}{*}{$t$} & \multirow{2}{*}{ Sig. } & \multicolumn{2}{|c|}{$\begin{array}{c}\text { Collinearity } \\
\text { Statistics }\end{array}$} \\
\hline & & $B$ & $\begin{array}{c}\text { Std. } \\
\text { Error }\end{array}$ & & & & $\begin{array}{c}\text { Toleranc } \\
e \\
\end{array}$ & $V I F$ \\
\hline \multirow[t]{4}{*}{1} & (Constant) & 8.790 & .410 & & 21.459 & .000 & & \\
\hline & $X_{l}=\mathrm{CAR}$ & -.009 & .006 & -.040 & -1.491 & .138 & .842 & 1.188 \\
\hline & $X_{2}=\mathrm{BOPO}$ & -.087 & .003 & -.829 & -28.401 & .000 & .702 & 1.424 \\
\hline & & & & 107 & & & & \\
\hline
\end{tabular}


IDEI: JURNAL EKONOMI \& BISNIS, VOL. 1, NO. 2, DESEMBER 2020: 99-110

\begin{tabular}{rrrrrrrr}
$X_{3}=\mathrm{NPL}$ & -.017 & .021 & -.022 & -.824 & .411 & .822 & 1.216 \\
$X_{4}=\mathrm{NIM}$ & .149 & .016 & .268 & 9.488 & .000 & .747 & 1.339 \\
$X_{5}=\mathrm{LDR}$ & -.004 & .002 & -.047 & -1.745 & .083 & .820 & 1.220 \\
\hline
\end{tabular}

a. Dependent Variable: $Y=\mathrm{ROA}$

Berlandaskan angka konstanta dan koefisien regresi pada Tabel 7, maka kaitan setiap variabel bebas serta variabel terikat pada model regresi seperti ini:

$\mathrm{ROA}=\beta_{0}+\beta_{1} \mathrm{CAR}+\beta_{2} \mathrm{BOPO}+\beta_{3} \mathrm{NPL}+\beta_{4} \mathrm{NIM}+\beta_{5} \mathrm{LDR}+\mu_{i}$

$\mathrm{ROA}=8,790-0,009 \mathrm{CAR}-0,087 \mathrm{BOPO}-0,017 \mathrm{NPL}+0,149 \mathrm{NIM}-0,004 \mathrm{LDR}+\mu_{i}$

\section{Uji Parsial (Uji t)}

\section{Uji Hipotesis}

1. CAR $\left(X_{I}\right)$ tidak berdampak dengan arah negatif dan (tidak nyata) pada ROA $(Y)$, atau tidak mampu diterima pada taraf [Sig. 0,138>0,10 : tidak signifikan dengan arah negatif.

2. $\mathrm{BOPO}\left(X_{2}\right)$ berdampak dengan arah negatif dan (nyata) pada ROA $(Y)$, atau mampu diterima pada taraf [Sig. $0,000<0,10$ : signifikan dengan arah negatif.

3. NPL $\left(X_{3}\right)$ tidak berdampak dengan arah negatif dan (tidak nyata) pada ROA $(Y)$, atau tidak mampu diterima pada taraf [Sig. 0,411>0,10: tidak signifikan dengan arah negatif.

4. NIM $\left(X_{4}\right)$ berdampak dengan arah positif dan (nyata) pada ROA $(Y)$, atau mampu diterima pada taraf [Sig. $0,000<0,10$ : signifikan dengan arah positif.

5. LDR $\left(X_{5}\right)$ berdampak dengan arah negatif dan (nyata) pada ROA $(Y)$, atau mampu diterima pada taraf [Sig. $0,083<0,10:$ signifikan dengan arah negatif.

\section{Uji Simultan (Uji F)}

Tabel 8

Hasil Uji Simultan (Uji F)

\begin{tabular}{|c|c|c|c|c|c|c|}
\hline & Model & Sum of Squares & $d f$ & Mean Square & $F$ & Sig. \\
\hline \multirow[t]{2}{*}{1} & Regression & 137.665 & 5 & 27.533 & 309.716 & $.000^{\mathrm{b}}$ \\
\hline & $\begin{array}{l}\text { Residual } \\
\text { Total }\end{array}$ & $\begin{array}{r}11.112 \\
148.777\end{array}$ & $\begin{array}{l}125 \\
130\end{array}$ & .089 & & \\
\hline
\end{tabular}

a. Dependent Variable: $Y=\mathrm{ROA}$

b. Predictors: $($ Constant $), X_{5}=\mathrm{LDR}, X_{3}=\mathrm{NPL}, X_{1}=\mathrm{CAR}, X_{4}=\mathrm{NIM}, X_{2}=\mathrm{BOPO}$

Dilihat pada nilai $F_{\text {hitung }}=309,716$ dengan Sig. $0,00<0,10$ : Signifikan positif, artinya transisi kelima variabel CAR $\left(X_{1}\right)$, BOPO $\left(X_{2}\right)$, NPL $\left(X_{3}\right)$, NIM $\left(X_{4}\right)$ dan LDR $\left(X_{5}\right)$, mampu menjelaskan perubahan variabel ROA (Y). Dengan Hasil tersebut dapat diketahui model regresi yang dipakai cocok atau sesuai artinya bisa menggunakan teknik analisis ini.

Pada Tabel 9 didapatkan angka koefisien determinasi $\left(R^{2}\right)$ diangka $0,925 \%$ atau $92,5 \%$, sehingga variabel independen bisa menerangkan variabel dependen setinggi $92,5 \%$ serta sisa 7,5\% [100\% - 92,5\%] diterangkan oleh variabel yang lain selain variabel CAR $\left(X_{1}\right)$, BOPO $\left(X_{2}\right)$, NPL $\left(X_{3}\right)$, NIM $\left(X_{4}\right)$, dan LDR $\left(X_{5}\right)$ Hasil ini mendeskripsikan terdapat ikatan yang cukup kuat pada variabel bebas secara simultan dengan variabel terikat.

\section{Uji R Square}

Tabel 9

Hasil Uji Perhitungan $R$ Square

\begin{tabular}{|c|c|c|c|c|c|c|c|}
\hline \multirow{2}{*}{ Model } & \multirow{2}{*}{$R$} & \multirow{2}{*}{$R$ Square } & \multirow{2}{*}{$\begin{array}{l}\text { Adjusted } R \\
\text { Square }\end{array}$} & \multirow{2}{*}{$\begin{array}{l}\text { Std. Error of } \\
\text { the Estimate }\end{array}$} & \multicolumn{2}{|c|}{ Change Statistics } & \multirow{2}{*}{$\begin{array}{l}\text { Durbin- } \\
\text { Watson }\end{array}$} \\
\hline & & & & & $\begin{array}{c}\text { R Square } \\
\text { Change }\end{array}$ & $\begin{array}{c}\text { Sig. F } \\
\text { Change }\end{array}$ & \\
\hline
\end{tabular}




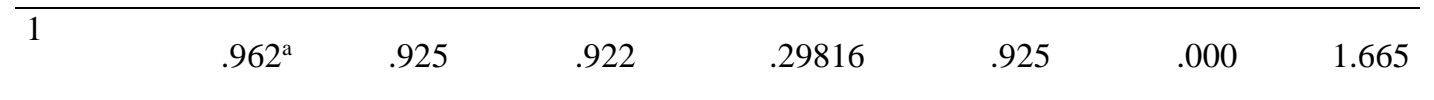

a. Predictors: (Constant), $X_{5}=\mathrm{LDR}, X_{3}=\mathrm{NPL}, X_{1}=\mathrm{CAR}, X_{4}=\mathrm{NIM}, X_{2}=\mathrm{BOPO}$

b. Dependent Variable: $Y=\mathrm{ROA}$

\section{Pembahasan}

Variabel Capital Adequecy Ratio (CAR) dari hasil observasi bisa dinyatakan jika tidak mempunyai dampak yang signifikan pada ROA. Sebagaimana perolehan observasi Pinasti dan Mustikawati (2018), Purnomo dkk. (2018), dan Korri dan Baskara (2019) yang membuktikan jika CAR tidak berdampak signifikan pada ROA. CAR tidak mempunyai dampak pada ROA ini karena peraturan BI (Bank Indonesia) yang mengharuskan bank memperhatikan CAR pada nilai minimal 8\%, sehingga berakibat bank mampu menyediakan cadangan dana untuk mencukupi nilai minimun CAR serta mengantisipasi jika terjadi risiko kredit. Oleh karena itu, meskipun bank memiliki permodalan besar dan tingkatan CAR cukup tinggi, jika tidak mampu mengimbangi dengan investasi serta pemberian dana secara baik, sehingga CAR tidak memiliki dampak luas pada ROA.

Variabel Beban Operasional dan Pendapatan Operasional (BOPO) pada hasil observasi bisa dinyatakan bahwa mempunyai dampak negatif serta signifikan pada Return On Assets (ROA). Sebagaimana hasil observasi dari Pinasti dan Mustikawati (2018), Purnomo dkk. (2018), Korri dan Baskara (2019), dan Dewi (2017) yang membuktikan BOPO berdampak negatif serta signifikan pada ROA. BOPO mempunyai dampak negatif artinya apabila BOPO mengalami kenaikan yang dimaksud menurunnya tingkat efisiensi, maka ROA terjadi penurunan. Ini dikarenakan pada tiap kenaikan beban operasi bank yang dapat menyebabkan menurunnya laba sebelum pajak, dan kemudian ROA akan menurun. Jika bank semakin efisien, maka kinerja bank juga semakin baik. Apabila bank mampu meningkatkan kinerjanya, maka juga menigkatkan kepercayaan msyarakat kepada bank. Jika aktivitas operasional dijalankan secara efisien (bila rasio BOPO kecil), maka profitabilitas yang didapatkan dapat naik juga.

Variabel Non Performing Loan (NPL) dari perolehan observasi bisa dinyatakan jika tidak mempunyai efek signifikan pada ROA. Sebagaimana hasil observasi dari Purnomo dkk. (2018), Pinasti dan Mustikawati (2018), dan Nugroho dkk. (2019) yang membuktikan bahwa NPL tidak memiliki efek signifikan pada ROA. Hal ini disebabkan oleh penyaluran kredit yang tinggi dan diikuti kredit macet mengalami kenaikan dan bank kurang pengawasan dalam penyaluran kredit, sehingga NPL tidak begitu mempengaruhi profitabilitas. Seharusnya bank memperhatikan juga peraturan penyaluran kredit yang di tetapkan oleh Bank Indonesia, sehingga dalam penyaluran kredit pada nasabah lebih diperketat agar tingkat kredit macet dapat lebih diperkecil.

Variabel Beban Net Interest Margin (NIM) dari hasil observasi bisa dinyatakan bahwa mempunyai dampak positif serta signifikan pada ROA. Sebagaimana penilaian observasi Purnomo dkk. (2018), Pinasti dan Mustikawati (2018), dan Nugroho dkk. (2019) yang membuktikan rasio NIM berdampak positif serta signifikan pada ROA. NIM mengindikasikan risiko pasar yang muncul akibat terjadi pergerakan rasio pasar, dalam hal ini dapat berdampak pada laba rugi bank. Jika rasio NIM makin tinggi, maka penghasilan bunga bersih juga mengalami peningkatan, sehingga dapat memberikan dampak pada profitabilitas bank. Bank bisa dikatakan memiliki kinerja yang baik atau bisa dikatakan kondisi bermasalah yang kecil apabila penghasilan bunga bersih cukup besar bisa menaikkan keuntungan sebelum pajak. Bisa disimpulkan jika makin tinggi NIM, maka makin tinggi pula profitabilitasnya.

Variabel Loan to Deposit Ratio (LDR) dari hasil observasi bisa dinyatakan bahwa mempunyai dampak negatif serta signifikan pada ROA. Sebagaimana penilaian observasi Dewi (2017) dan Korri dan Baskara (2019) yang membuktikan bahwa LDR berdampak negatif serta signifikan pada ROA. LDR menggambarkan kapasitas bank saat melunasi lagi penarikan dana yang dilakukan oleh deposan degn menggunakan kredit yang disetorkan guna sumber likuiditasnya. Bank yang tidak bisa memberikan kredit secara efisien dan tidak memberikan batas toleran, maka akan menimbulkan masalah yaitu naiknya kredit macet, sehingga akan menurunkan profitabilitas.

\section{Simpulan dan Saran}


Capital Adequecy Ratio (CAR) tidak memberikan partisipasi pada kenaikan ROA perusahaan perbankan yang tercatat pada BEI rentan waktu 2014-2018. Kondisi tersebut menjelaskan naik dan turunnya CAR tidak memberikan dampak pada keputusan ROA perusahaan. Beban Operasional dan Pendapatan Operasional (BOPO) mampu memberikan kontribusi pada ROA perusahaan perbankan yang tercatat pada BEI rentan waktu 2014-2018. Kondisi tersebut menjelaskan meningkatnya BOPO di sisi lain akan menurunkan ROA dan begitupun sebaliknya. Non Performing Loan (NPL) tidak mampu memberikan kontribusi pada kenaikan ROA perusahaan perbankan yang tercatat pada BEI rentang waktu 2014-2018. Kondisi tersebut menjelaskan naik dan turunnya NPL tidak memberikan dampak pada keputusan ROA perusahaan Net Interest Margin (NIM) memberikan partisipasi pada kenaikan ROA perusahaan perbankan yang tercatat pada BEI rentang waktu 2014-2018. Kondisi tersebut menjelaskan meningkatnya NIM di sisi lain perusahaan akan mengalami kenaikan pula terhadap ROA dan begitu juga sebaliknya. Loan to Deposit Ratio (LDR) mampu memberikan kontribusi pada ROA perusahaan perbankan yang tercatat pada BEI rentang waktu 2014-2018. Kondisi tersebut menjelaskan meningkatnya LDR di sisi lain akan menurunkan ROA dan begitupun sebaliknya.

Bagi observasi berikutnya yang akan melaksanakan riset dengan topik yang sama sebaiknya memakai variabel yang lebih beragam dan bisa memperbarui rentan waktu observasi, memakai perusahaan perbankan lainnya, dan melakukan pengukuran variabel selain yang bisa memberi dampak pada kinerja Bank. Untuk penelitian berikutnya disarankan dalam menetapkan sampel penelitian setidaknya menggunakan kriteria bank yang memiliki Return On Assets positif maupun Return On Assets negatif, sehingga bisa memperoleh hasil yang komprehensif.

\section{Referensi}

Cryer \& Miller, (1994). Statistics for business data analysis and modeling. California: International Thomson Publishing.

Dewi, A. S. (2017). Pengaruh car, bopo, npl, nim, dan ldr terhadap roa pada perusahaan di setor perbankan yang terdaftar di BEI periode 2012-2016. Jurnal Pundi, 01(03), 223-236.

Kasmir, (2014). Analisis laporan keuangan. Edisi Pertama. Cetakan Ketujuh. Jakarta: PT. Rajagrafindo Persada.

Korri, N. T. L., \& Baskara, I. G. K. (2019). Pengaruh capital adequecy ratio, non performing loan, bopo, dan loan to deposit ratio terhadap profitabilitas. E-Jurnal Manajeman, 8(11), 6557-6597. https://doi.org/10.24843/EJMUNUD.2019.v08.i11.p10

Nugroho, D., Mangantar, M., \& Tulung, J. E. (2019). Pengaruh car, bopo, nim, dan npl terhadap roa industri bank umum swasta nasional buku 3 periode 2014-2018. Junal EMBA, 7(3), 42224229. https://doi.org/10.35794/emba.v7i3.25038

Peraturan Bank Indonesia No. 13/1/PBI/2011 tanggal 5 Januari 2011 tentang penilaian tingkat kesehatan bank umum.

Pinasti, W. F., \& Mustikawati, R. R. I. (2018). Pengaruh car, bopo, npl, nim, dan ldr terhadap profitabilitas bank umum periode 2011-2015. Jurnal Nominal, 7(1), 126-142.

Purnomo, E., Sriwidodo, U., \& Wibowo, E. (2018). Pengaruh rasio keuangan terhadap kinerja keuangan pada bank umum swasta nasional devisa yang terdaftar di Bursa Efek Indonesia periode 2013-2016. Jurnal Ekonomi dan Kewirausahaan, 18, 189-198.

Sekaran, U. (2006). Metodologi penelitian untuk bisnis. Buku 2. Edisi 4. Jakarta: Salemba Empat.

Siswanto, S. (2004). Mengenal arti dan penggunaan neraca perusahaan. Jakarta: Damar Mulia Pustaka.

Surat Edaran Bank Indonesia No. 6/23/DPNP tanggal 31 Mei 2004 tentang sistem penilaian tingkat kesehatan bank umum dan lampiran.

Surat Edaran Bank Indonesia No. 13/24/DPNP tanggal 25 Oktober 2011 tentang penilaian tingkat kesehatan bank umum. 